\title{
Association of severe asthma attacks with weather, pollen, and air pollutants
}

\author{
O V J Rossi, V L Kinnula, J Tienari, E Huhti
}

\begin{abstract}
Background The association between exacerbations of asthma and weather or air pollution is not well understood. The relationships between visits to the emergency room for asthma attacks and the meteorological, aerobiological, and chemical characteristics of the outdoor air have been evaluated.

Methods The number of daily attendances for asthma attacks at the emergency room of Oulu University Central Hospital was recorded over one year together with daily meteorological readings (temperature, humidity, barometric pressure, rainfall), levels of air pollutants (nitrogen dioxide $\left(\mathrm{NO}_{2}\right)$, sulphur dioxide $\left(\mathrm{SO}_{2}\right)$, hydrogen sulphide $\left(\mathrm{H}_{2} \mathrm{~S}\right)$, total suspended particles (TSP)), and pollen counts (birch, alder, pine, willow, total pollen). The relationship between the number of attendances and the measured variables was then analysed by multiple regression and stepwise discriminant analysis.
\end{abstract}

Results The total number of attendances during the year was 232 , with lower figures in summer and higher in winter. No association was found between visits for asthma attacks and airborne pollen levels or meteorological factors except for temperature, which had a low inverse correlation with attendance. The most significant correlations were found between asthma visits and the levels of $\mathrm{NO}_{2}$; those for $\mathrm{SO}_{2}$, TSP, and $\mathrm{H}_{2} \mathrm{~S}$ were also significant. Intercorrelations between $\mathrm{SO}_{2}$ and temperature or $\mathrm{NO}_{2}$ and between temperature and TSP or $\mathrm{NO}_{2}$ were also found, but only $\mathrm{NO}_{2}$ correlated significantly with attendances after standardisation for temperature.

Conclusions Increased levels of pollutants, especially $\mathrm{NO}_{2}$, were associated with attacks of asthma, but the explanation for this is unclear. Air pollen levels were not associated with asthma attacks and only temperature among the meteorological factors had a small association with asthma.

(Thorax 1993;48:244-248)

Although morbidity and mortality from asth- ma seem to be increasing in many countries the causes of these increases are not clear. ${ }^{12}$ The importance of virus infections in exacerbations of asthma has been shown by many authors, ${ }^{3-5}$ but the role of weather conditions, pollen, and other air pollutants remains controversial, even though a number of asthma "epidemics" suggest that environmental factors often trigger exacerbations. ${ }^{6-11}$

Weather changes may affect the airways directly by cooling or irritating them or indirectly by influencing the level of airborne irritants and allergens. Exacerbations of asthma have been shown to correlate with low temperature and humidity ${ }^{10}$ or a sudden fall in temperature,,$^{1213}$ and associations between asthma admissions and low or high barometric pressure ${ }^{1415}$ and rainfall have also been observed. ${ }^{614}$

Levels in the air of grass and ragweed pollen and fungal spores are associated with increased symptoms in susceptible subjects. ${ }^{16} 17$ Levels of small particle antigenic material in the air correlate with temperature and relative humidity, so the interaction of pollen with weather may account for some of the difficulties encountered in demonstrating their effects on asthma. ${ }^{18}$

The prevalence of asthma and the frequency of symptoms have been found to be higher in polluted than in non-polluted areas, ${ }^{19} 20$ and an association of symptoms with specific contaminants-for example, sulphur dioxide or nitrogen dioxide-has been shown experimentally. ${ }^{2122}$ The position in "normal" air pollution, however, is different and an increase in one contaminant is often accompanied by an increase in others, which obscures independent effects. The purpose of this study was to examine any relationship between severe exacerbations of asthma and weather conditions or concentrations of pollen and other ambient pollutants.

\section{Methods}

Oulu is an industrial town in northern Finland with a population of about 100000 on the coast of the Gulf of Bothnia. It has major variations in weather conditions in the course of the year. The main sources of air pollution were a pulp mill, a chemicals factory producing fertilisers, and two heating plants, all of which are located within three kilometres of the city centre. 
PATIENTS

All the adult patients (aged 15-85 years) attending the emergency room at Oulu Univesity Central Hospital for asthma attacks during one year from 1 October 1985 to 30 September 1986 were included. The diagnosis of asthma was based on the variability of airways obstruction and all the patients fulfilled the criteria for asthma as proposed by the American Thoracic Society. ${ }^{23}$ The diagnosis of asthma was confirmed by one of the two senior respiratory physicians (VLK, EH) at the emergency room every morning.

\section{WEATHER}

Maximum, minimum, and mean daily temperatures were measured at the meteorological station of the city of Oulu, and relative humidity, barometric pressure, and rainfall at Oulu airport, 15 kilometres from the city centre.

\section{POLLEN}

The concentrations of birch, alder, pine, willow, and total pollen were measured with a Burkard trap from March to October, the period when substantial amounts of pollen are present in the air in this area. The trap was managed by the Department of Botany at the University of Oulu and was placed on the roof of a building about 15 metres above the ground and three kilometres from the city centre. Detailed analysis was performed by the Finnish Aerobiology Group in Turku.

\section{POLLUTION}

Nitrogen dioxide $\left(\mathrm{NO}_{2}\right)$, sulphur dioxide $\left(\mathrm{SO}_{2}\right)$, hydrogen sulphide $\left(\mathrm{H}_{2} \mathrm{~S}\right)$, and total suspended particles (TSP) were measured at four points around Oulu. $\mathrm{SO}_{2}$ was measured with a Philips PW 9755/00 analyser and $\mathrm{H}_{2} \mathrm{~S}$ with a Philips PW 9766/01 analyser, both with the coulometric titration method. $\mathrm{NO}_{2}$
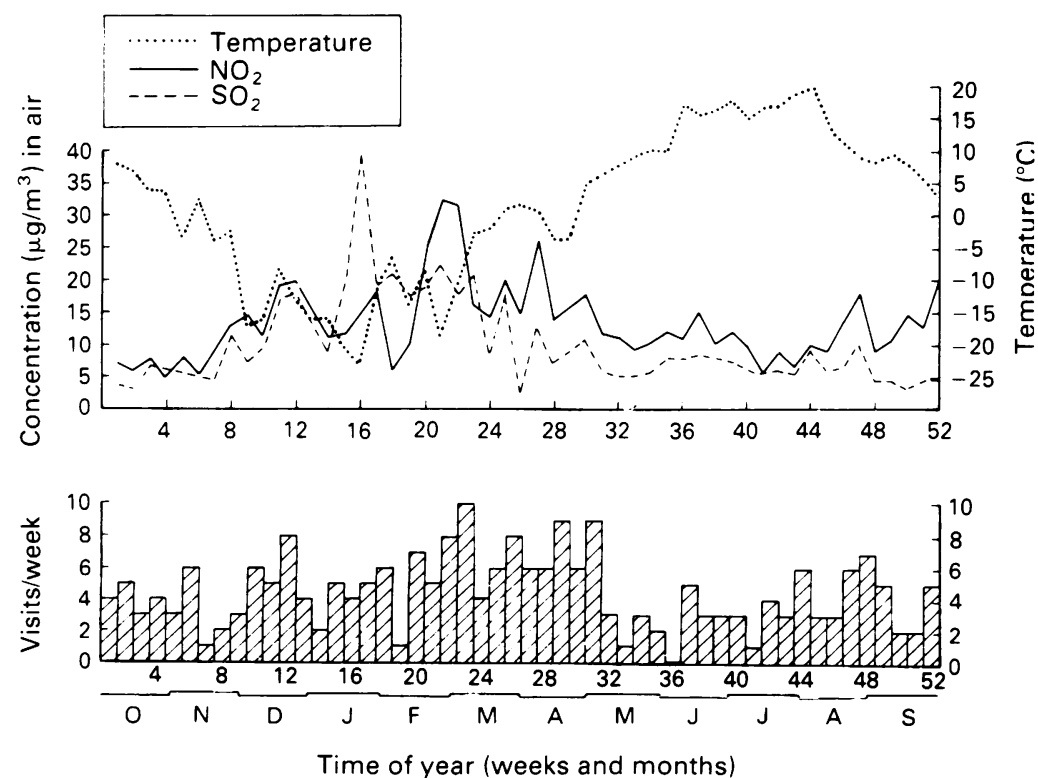

Weekly emergency room visits for asthma attacks in relation to weekly mean temperature levels and $\mathrm{NO}_{2}$ and $\mathrm{SO}_{2}$ concentrations during the period studied. was measured with a Monitor Laboratories Model 8840 analyser by chemiluminescence. TSP were measured with a Philips PW 9790/00 device using the absorption of $\beta$ radiation. Maximum concentrations of pollutants measured over one hour and mean daily concentrations were recorded.

\section{STATISTICS}

Pearson's correlation coefficient and partial correlations calculated with BMDP statistical software ${ }^{24}$ were used to describe the relation between the number of admissions and the variables measured. The stepwise discriminant analysis of BMDP and multiple regression analysis was used to check the results of the correlation analysis.

\section{Results}

ATTENDANCES

There were 232 attendances at the hospital for asthma during the year, with daily numbers varying from zero to six. The mean (range) age of the patients was 50 (15-85) years and $42 \%$ of them were men. There was an obvious seasonal variation in visits, the numbers being lower in summer and higher in winter (figure).

\section{WEATHER, POLLEN, AND POLLUTANTS}

The daily mean temperature during the year varied from $-28^{\circ} \mathrm{C}$ in January to $+20^{\circ} \mathrm{C}$ in July, the average for the year being $+1 \cdot 4^{\circ} \mathrm{C}$. The daily mean relative humidity varied from $34 \%$ to $98 \%$, barometric pressure from 977 to 1048 millibars, and rainfall from $0 \mathrm{~mm}$ to $54 \mathrm{~mm}$ per day.

The highest daily mean concentration of total pollen (4050 grains $/ \mathrm{m}^{3}$ ) was measured in the middle of June; the highest single pollen concentration for birch (4015 grains $/ \mathrm{m}^{3}$ ) was also measured in June, and that for pine (2145 grains $/ \mathrm{m}^{3}$ ) at the end of May, while the other pollen types remained below 300 grains $/ \mathrm{m}^{3}$.

Concentrations of $\mathrm{SO}_{2}, \mathrm{H}_{2} \mathrm{~S}, \mathrm{NO}_{2}$, and TSP in the air were recorded as daily means

Table 1 Daily mean and maximum concentrations $\left(\mu \mathrm{g} / \mathrm{m}^{3}\right)$ of ambient air pollutants during the year and air quality guidelines developed by $\mathrm{WHO}^{\star}$

\begin{tabular}{|c|c|c|c|}
\hline \multirow[b]{2}{*}{ Pollutant } & \multicolumn{2}{|c|}{ During the year } & \multirow{2}{*}{$\begin{array}{l}\text { Air quality } \\
\text { guidelines from } \\
W H O^{\star}\end{array}$} \\
\hline & Mean & Range & \\
\hline \multicolumn{4}{|l|}{$\mathrm{SO}_{2}$} \\
\hline Daily mean & $10 \cdot 0$ & $0-56$ & 125 \\
\hline Daily maximum & $31 \cdot 0$ & $1-241$ & 350 \\
\hline \multicolumn{4}{|l|}{$\mathrm{H}_{2} \mathrm{~S}$} \\
\hline Daily mean & $3 \cdot 1$ & $0-34$ & 150 \\
\hline Daily maximum & $15 \cdot 4$ & $0-172$ & - \\
\hline \multicolumn{4}{|l|}{$\mathrm{NO}_{2}$} \\
\hline Daily mean & $13 \cdot 4$ & $0-69$ & 150 \\
\hline Daily maximum & $38 \cdot 5$ & $0-154$ & 400 \\
\hline \multicolumn{4}{|l|}{ TSP } \\
\hline Daily mean & $18 \cdot 3$ & 0-90 & 120 \\
\hline Daily maximum & 38.5 & $0-202$ & - \\
\hline
\end{tabular}

$\mathrm{SO}_{2}$ - sulphur dioxide; $\mathrm{H}_{2} \mathrm{~S}$-hydrogen sulphide; $\mathrm{NO}_{2}-$ nitrogen dioxide; TSP - total suspended particles. Daily mean-24 hour mean concentration; daily maximumlargest one hour mean concentration during the day. 
Table 2 Pearson correlation coefficients between pollutants or weather variables and daily visits for asthma attacks on the previous day, the same day (day of attack) and the next two days during the whole year and also on the same day as an attack separately in summer and in winter

\begin{tabular}{|c|c|c|c|c|c|c|}
\hline \multirow[b]{3}{*}{$\begin{array}{l}\text { Pollutants and } \\
\text { weather variables }\end{array}$} & \multicolumn{6}{|c|}{ Visits to emergency room for asthma } \\
\hline & \multicolumn{4}{|c|}{ During the whole year } & \multirow[b]{2}{*}{$\begin{array}{l}\text { In winter } \\
\text { (same day) }\end{array}$} & \multirow[b]{2}{*}{$\begin{array}{l}\text { In summer } \\
\text { (same day) }\end{array}$} \\
\hline & $\begin{array}{l}\text { Previous } \\
\text { day }\end{array}$ & $\begin{array}{l}\text { Same } \\
\text { day }\end{array}$ & $\begin{array}{l}\text { First next } \\
\text { day }\end{array}$ & $\begin{array}{l}\text { Second next } \\
\text { day }\end{array}$ & & \\
\hline $\mathrm{SO}_{2}$ & 0.04 & $0 \cdot 13^{\star \star}$ & 0.05 & 0.08 & 0.11 & 0.02 \\
\hline $\mathrm{H}_{2} \mathrm{~S}$ & -0.06 & 0.09 & 0.07 & 0.01 & $0 \cdot 11$ & 0.05 \\
\hline $\mathrm{NO}_{2}$ & 0.04 & $0 \cdot 20^{\star \star \star}$ & $0 \cdot 14^{\star \star}$ & $0 \cdot 12^{\star}$ & $0 \cdot 27^{\star \star \star}$ & 0.01 \\
\hline TSP & 0.02 & $0 \cdot 13^{\star \star}$ & 0.04 & 0.05 & 0.02 & $0 \cdot 15^{\star}$ \\
\hline Temperature & -0.08 & -0.09 & -0.08 & $-0 \cdot 11^{\star}$ & 0.06 & -0.05 \\
\hline Humidity & 0.05 & 0.07 & $0 \cdot 10^{\star}$ & 0.08 & -0.09 & 0.05 \\
\hline Barometric pressure & 0.00 & 0.02 & -0.04 & -0.03 & -0.01 & 0.02 \\
\hline Rainfall & 0.03 & -0.08 & 0.02 & 0.07 & -0.03 & -0.04 \\
\hline
\end{tabular}

${ }^{\star} \mathrm{p}<0.05 ;{ }^{\star \star} \mathrm{p}<0.01 ;{ }^{\star \star \star} \mathrm{p}<0.001$.

$\mathrm{SO}_{2}$ - sulphur dioxide; $\mathrm{H}_{2} \mathrm{~S}$-hydrogen sulphide; $\mathrm{NO}_{2}$-nitrogen dioxide; $\mathrm{TSP}$ - total suspended particles.

(24 hour mean concentrations) and daily maxima (largest one hour mean concentration during the day). The average daily means and means of daily maxima are shown in table 1, which also indicates the air quality guidelines developed by the WHO.

The weekly mean concentrations of $\mathrm{SO}_{2}$ and $\mathrm{NO}_{2}$ are shown in the figure, together with mean weekly temperatures and weekly numbers of attendances. The concentrations of $\mathrm{SO}_{2}, \mathrm{TSP}$, and $\mathrm{NO}_{2}$ were correlated with temperature: $r=-0.66,-0.53$, and -0.44 respectively $(p<0.001)$. Significant correlations were observed between $\mathrm{NO}_{2}$ and $\mathrm{SO}_{2}$ $(\mathrm{r}=0.48, \mathrm{p}<0.001)$ and between $\mathrm{SO}_{2}$ and $\operatorname{TSP}(\mathrm{r}=0.31, \mathrm{p}<0.01)$.

Table 3 Pearson correlation coefficients between pollutants or weather variables and weekly visits for asthma attacks during the same or the next week and between all emergency room visits, and partial correlations for the asthma visits in the same week after standardisation of temperature

\begin{tabular}{|c|c|c|c|c|}
\hline \multirow{3}{*}{$\begin{array}{l}\text { Pollutants and } \\
\text { weather variables }\end{array}$} & \multicolumn{3}{|c|}{ Visits to emergency room } & \multirow{3}{*}{$\begin{array}{l}\text { Partial correlations } \\
\text { for asthma visits } \\
\text { in same week }\end{array}$} \\
\hline & \multirow{2}{*}{$\begin{array}{l}\text { All visits } \\
\text { (same week) }\end{array}$} & \multicolumn{2}{|c|}{ Asthma visits } & \\
\hline & & Same week & Next week & \\
\hline $\mathrm{SO}_{2}$ & -0.03 & $0 \cdot 28^{\star}$ & $0 \cdot 30^{\star}$ & $0 \cdot 16$ \\
\hline $\mathrm{H}_{2} \mathrm{~S}$ & $0 \cdot 16$ & $0 \cdot 24^{\star}$ & $0 \cdot 15$ & $0 \cdot 26^{\star}$ \\
\hline $\mathrm{NO}_{2}$ & 0.03 & $0 \cdot 42^{\star \star \star}$ & $0.58^{\star \star \star}$ & $0 \cdot 36^{\star \star}$ \\
\hline TSP & $0 \cdot 17$ & $0 \cdot 24^{\star}$ & $0 \cdot 20$ & $0 \cdot 13$ \\
\hline Temperature & -0.05 & $-0 \cdot 25^{\star}$ & $-0 \cdot 36^{\star \star}$ & \\
\hline Humidity & 0.06 & $0 \cdot 21$ & $0 \cdot 20$ & 0.03 \\
\hline Barometric pressure & $-0 \cdot 14$ & -0.08 & 0.07 & -0.09 \\
\hline Rainfall & $-0 \cdot 16$ & -0.07 & $-0 \cdot 16$ & -0.01 \\
\hline
\end{tabular}

${ }^{\star} \mathrm{p}<0.05 ;{ }^{\star \star} \mathrm{p}<0.01 ;{ }^{\star \star \star} \mathrm{p}<0.001$.

$\mathrm{SO}_{2}$-sulphur dioxide; $\mathrm{H}_{2} \mathrm{~S}$-hydrogen sulphide; $\mathrm{NO}_{2}$-nitrogen dioxide; TSP-total suspended particles.

Table 4 Results of multiple regression analysis for association between attendances for asthma attacks and pollutants or temperature

\begin{tabular}{|c|c|c|c|c|c|c|}
\hline \multirow[b]{2}{*}{$\begin{array}{l}\text { Measured } \\
\text { variable }\end{array}$} & \multicolumn{2}{|l|}{ Whole year } & \multicolumn{2}{|l|}{ Winter } & \multicolumn{2}{|l|}{ Summer } \\
\hline & $\begin{array}{l}\text { Regression } \\
\text { coefficient }\end{array}$ & $p$ & $\begin{array}{l}\text { Regression } \\
\text { coefficient }\end{array}$ & $p$ & $\begin{array}{l}\text { Regression } \\
\text { coefficient }\end{array}$ & $p$ \\
\hline Intercept & $1 \cdot 858$ & 0.034 & 1.992 & 0.035 & $4 \cdot 379$ & 0.062 \\
\hline $\mathrm{NO}_{2}$ & 0.209 & 0.0001 & $0 \cdot 201$ & 0.014 & 0.041 & 0.714 \\
\hline $\mathrm{SO}_{2}$ & -0.037 & 0.535 & -0.024 & 0.710 & -0.003 & 0.991 \\
\hline $\mathrm{H}_{2} \mathrm{~S}$ & 0.038 & $0 \cdot 740$ & 0.132 & 0.519 & 0.351 & $0 \cdot 125$ \\
\hline Temperature & -0.039 & $0 \cdot 258$ & 0.008 & $0 \cdot 880$ & $-0 \cdot 177$ & 0.035 \\
\hline $\mathbf{r}^{2}$ & \multicolumn{2}{|c|}{0.389} & \multicolumn{2}{|c|}{0.497} & \multicolumn{2}{|c|}{0.389} \\
\hline $\mathrm{p}$ & \multicolumn{2}{|c|}{0.0001} & \multicolumn{2}{|c|}{0.0062} & \multicolumn{2}{|c|}{0.029} \\
\hline
\end{tabular}

$\mathrm{NO}_{2}$-nitrogen dioxide; $\mathrm{SO}_{2}$ - sulphur dioxide; $\mathrm{H}_{2} \mathrm{~S}$ - hydrogen sulphide
RELATIONS BETWEEN ATTENDANCES AND

WEATHER, POLLEN, OR POLLUTANTS

No association was found between concentrations of pollen in the air and attendances for attacks of asthma, the former being highest in early summer, when the number of attendances was low. The correlations between daily attendances and the meteorological variables and the air concentrations of pollutants are presented in table 2 . Of the meteorological variables recorded, a low but significant correlation was found only between attendances and humidity or temperature.

Attendances during the whole year were most closely correlated with levels of $\mathbf{N O}_{2}$ $(r=0.20, p<0.001)$ and significant correlations also existed with $\mathrm{SO}_{2}$ and TSP. The significance of the correlations disappeared with a lag of one or two days for pollutants other than $\mathrm{NO}_{2}$. In view of the great variation in attendances and measured variables during the year, the associations were also evaluated separately for the winter and summer periods. Only the correlation for $\mathrm{NO}_{2}$ remained significant in winter and that for TSP in the summer period. For control purposes correlations were also calculated between the concentrations on a given day and attendances on the previous day, and these were definitely lower for all the pollutants.

Since the number of daily attendances was low, correlations were also calculated between weekly numbers of attendances and weekly mean concentrations of the pollutants (table 3). These were much higher for all the factors measured but only $\mathrm{H}_{2} \mathrm{~S}$ became significant in addition to those identified on a daily basis. Partial correlations after standardisation for temperature are also shown in table 3 , as are the correlations between pollutants or weather variables and all emergency room visits (both for asthma and all other medical conditions) for control purposes.

To evaluate the relative importance of the various factors measured multiple regression analyses and discriminant analyses were carried out both for the whole year and separately for the winter and summer periods. In the stepwise procedure on a daily basis for the whole year only $\mathrm{NO}_{2}$ was significantly associated with admissions $(\mathrm{p}<0.001)$. In winter 
there was an almost significant correlation for temperature $(p<0.05)$ in addition to that for $\mathrm{NO}_{2}$, and in summer the temperature was most strongly associated with admissions $(p<$ $0.01)$ followed by $\mathrm{H}_{2} \mathrm{~S}(\mathrm{p}<0.05)$. The results of the stepwise discriminant analysis were similar; only $\mathrm{NO}_{2}$ was selected in the discriminant function. The days with infrequent attendances were correctly classified in $71 \%$ of cases, but those with frequent attendances in only $46 \%$ of cases. The results of the regression analysis in which only pollutants and temperature are included are shown in table 4 .

\section{Discussion}

The attendances recorded here represent the number of severe attacks of asthma in the area as the University Hospital was the only emergency unit available and all asthma patients visiting the emergency room were included whether subsequently admitted to hospital or discharged directly. The quality of the air around Oulu has been monitored since 1970 so the methods used and the network of measurement points have been developed to obtain as accurate a picture as possible of the sources and levels of the main pollutants. The use of a Burkard trap to measure pollen concentration is a widely accepted method and the location of the trap makes it relatively representative of conditions in the area as a whole.

A seasonal variation in asthma attacks has been noted on many previous occasions ${ }^{25} 26$ but its causes are unknown. The single year of the present survey makes the evaluation of seasonal factors difficult, but attendances were lower in summer and higher in winter. Associations between asthma exacerbations and meteorological factors have been reported elsewhere. Carey and Cordon ${ }^{2 i}$ reported an association between asthma attacks and relative humidity, north easterly winds, and temperature in Bermuda even though temperature varied only from $+16^{\circ} \mathrm{C}$ to $+27^{\circ} \mathrm{C}$. The variation in temperature in this study was much greater (daily means from $-28^{\circ} \mathrm{C}$ to $+28^{\circ} \mathrm{C}$ ) and the association with attendances was closer in the warm summer period than in the winter. This may be because patients spend more time indoors in winter than in summer.

The symptoms of asthma in children in Austria have been shown to increase with levels of pollen in the air, particularly when the concentration of fungal spores was included. ${ }^{28}$ We did not measure spore counts, but found no relationship between attendance and pollen counts, total pollen in the air being highest in June when there were fewer asthma attacks. Our series consisted of adults of whom about $40 \%$ were atopic, so the reason for this discrepancy may be related to the age of the patients and their type of asthma.

Higher frequencies and more severe forms of asthma have been observed in polluted than in non-polluted areas in some previous reports. ${ }^{20} 2930$ Although the association with individual pollutants varies, $\mathrm{SO}_{2}$ has been most convincingly documented as detrimental for asthma. The evidence comes both from epidemiological surveys pointing to an association between asthma exacerbations and $\mathrm{SO}_{2}$ concentrations in the $\operatorname{air}^{142631}$ and from experiments in which asthmatic patients have been found to be more sensitive to $\mathrm{SO}_{2}$ than non-asthmatic patients. ${ }^{21}{ }^{32} 33$ We found a significant correlation between emergency attendances and levels of $\mathrm{SO}_{2}$, and this relationship became closer in winter than in summer. This difference is obviously due to the high intercorrelation between temperature and $\mathrm{SO}_{2}$ levels, and suggests a combined effect of these two variables in asthmatic patients.

There are fewer epidemiological surveys in which an association has been found between asthma admissions and levels of $\mathrm{NO}_{2}$ in the air, ${ }^{1134}$ and most of those with negative results were carried out under different climatic conditions from those in the present study. Experimental exposure to nitrogen oxides has shown that concentrations as low as 0.30 ppm increase the subsequent response to cold air in asthmatic patients. ${ }^{35}$ In spite of the relatively low concentrations of pollutants in the Oulu air we found a significant correlation between emergency room attendances and levels of $\mathrm{NO}_{2}$, which was stronger in winter than in summer. The low winter temperatures in Oulu may explain these results, which are in agreement with those obtained in an investigation into levels of pollutants and asthma admissions in Helsinki ${ }^{34}$ with similar weather and pollutant levels.

The mechanisms by which pollutants exert their effects on asthma are not clear, but the finding that small concentrations of $\mathrm{NO}_{2}$ in inhaled air $\left(210 \mathrm{mg} / \mathrm{m}^{3}\right)$ increase airway responsiveness to carbacholine ${ }^{36}$ or cold ${ }^{35}$ and create an inflammation detectable by bronchoalveolar lavage ${ }^{3 i}$ may represent a characteristic feature of the background effect of low level pollution on asthma. Current air pollution levels may be too low to cause attacks of asthma but they may irritate the airways and make them more sensitive to other triggers such as infection, allergens, or meteorological factors.

In summary, neither weather changes nor pollen levels directly precipitate severe attacks of asthma in adults. Air pollutants, especially $\mathrm{NO}_{2}$, seem to be associated with such exacerbations, but their interaction with meteorological factors makes it difficult to confirm the role of any one specific factor. These results obtained at relatively low air pollution levels nevertheless suggest that they do play some part in severe exacerbations of asthma and should be taken into account when standards for air pollution are reviewed.

This work was supported by grants from the Foundation for This work was supported by grants from the Foundation for
the Study of Allergy, Finland, and the Finnish Antituberculosis Association.

1 Khot A, Burn R. Seasonal variation and time trends of deaths from asthma in England and Wales 1960-82. deaths from asthma

2 Woolcock AJ. Worldwide differences in asthma prevalence 
and mortality. Chest 1986;90 (Suppl):S40-5.

3 Beasley R, Coleman ED, Hermon Y, Holst PE, O'Donnel TV, Tobias $M$. Viral respiratory tract infection and exacerbations of asthma in adult patients. Thorax 1988 ; 43:679-83.

4 Huhti E, Mokka T, Nikoskelainen J, Halonen P. Association of viral and mycoplasma infections with exacerbations of asthma. Ann Allergy 1974;33:145-9.

5 Smith AP. Patterns of recovery from acute severe asthma. Br 7 Dis Chest 1981;75:132-40.

6 Egan P. Weather or not. Med f Aust 1985;142:330.

7 Morrison I. It happened one night. Med f Aust 1960;47: $850-2$.

8 Packe GE, Ayres JG. Asthma outbreak during a thunderstorm. Lancet 1985;ii: 199-204.

9 Phelps HW, Koike S. "Tokyo-Yokohama asthma". Am Rev Respir Dis 1962;86:55-63.

10 Salvaggio J, Hasselblad V, Seabury J, Heiderscheid LT New Orleans asthma. II. Relationship of climatologic and seasonal factors to outbreaks. F Allergy 1970;45 257-65.

11 Ussetti P, Roca J, Agusti AGN, Montserrat JM Rodriguez-Roisin R, Agusti-Vidal A. Asthma outbreaks in Barcelona. Lancet 1983;ii:280-1.

12 Goldstein IF. Weather patterns and asthma epidemics in New York City and New Orleans, U S A. Int $\mathcal{f}$ Biometeorol 1980;24:329-39.

13 Tromp SW. Influence of weather and climate on asthma and bronchitis. Rev Allergy 1968;22:1027-44.

14 Khot A, Burn R, Evans N, Lenney W, Storr J Biometeorological triggers in childhood asthma. Clin Allergy 1988;18:351-8.

15 Grish LS, Shubin E, Dick C, Schulauer FA. A study on the epidemiology of asthma in children in Philadelphia. F Allergy 1967;39:347-57.

16 Hill DJ, Smart IJ, Knox RB. Childhood asthma and grass pollen aerobiology in Melbourne. Med f Aust 1979;1: 426-9.

17 Salvaggio J, Seabury J, Schoenhardt EA. New Orleans asthma. V. Relationship between Charity Hospital admission rates, semiquantitative pollen and fungal spore counts and total particulate aerometric sampling data. F Allergy Clin Immunol 1971;48:96-114.

18 Habenicht HA, Burge HA, Muilenberg ML, Solomon WR. Allergen carriage by atmospheric aerosol. II Ragweed pollen determinants in submicronic atmospheric fractions. $f$ Allergy Clin Immunol 1984;74:64-7.

19 Whittemore AS, Korn EL. Asthma and air pollution in the Los Angeles area. Am $\mathcal{F}$ Public Health 1980;70: 687-95.

20 Yoshida K, Oshima H, Imai M. Air pollution and asthma in Yokkaichi. Arch Environ Health 1976;15:684.

21 Linn WS, Venet TG, Shomoo A. Respiratory effects of sulfur dioxide in heavily exercising asthmatic. $A m R e v$ Respir Dis 1983;127:278-83.
22 Sheppard D, Wong WS, Uehera CF, Nadel JA, Boushey HA. Lower threshold and greater bronchomotor responsiveness of asthmatic subjects to sulfur dioxide. Am Rev Respir Dis 1980;122:873-8.

23 Definitions and classifications of chronic bronchitis, asthma and pulmonary emphysema: a statement by the American Thoracic Committee on the diagnostic standards for non-tuberculous respiratory diseases. $\mathrm{Am} \mathrm{Rev}$ Respir Dis 1962;85:762-8.

24 Dixon WJ. BMDP statistical software 1983: printing with additions. Berkeley, Los Angeles, London: University of California Press, 1983

25 Goldstein JF, Currie B. Seasonal patterns of asthma: a clue to etiology. Environ Res 1984;33:201-15.

26 Bates DV, Baker-Anderson M, Sizo R. Asthma attack periodicity: a study of hospital emergency visits in Vancouver. Environ Res 1990;51:51-70.

27 Carey MJ, Cordon I. Asthma and climatic conditions: experience from Bermuda, an isolated island community. $B M F$ 1986;293:843-5.

28 Klabuschnigg A, Götz M, Horak F, Jäger S, Machalek A Popov $C$, et al. Influence or aerobiology and weather symptoms in children with asthma. Respiration 1981;42 $52-60$

29 Sultz H, Feldman J, Schlesinger E. An effect of continued exposure to air pollution on the incidence of chronic childhood allergic diseases. Am 7 Public Health 1970;60: 891.

30 Kraemer MJ, McCarthy MM. Childhood asthma hospitalization rates in Spokane County, Washington: impact of volcanic ash air pollution. $\mathcal{F}$ Asthma 1985;22:37.

31 Bates, DV, Sizo R. Relationship between air pollutant levels and hospital admissions in southern Ontario. Can $\mathcal{F}$ Publ Health 1983;74:117-22.

32 Bethel RA, Sheppard D, Epstein J, Tam E, Nadel JA Boushey HA. Interaction of sulfur dioxide and dry cold air in causing bronchoconstriction in asthmatic subjects. Appl Physiol 1984;57:419-23.

33 Sheppard D, Saisho A, Nadel JA, Boushey HA. Exercise increases sulfur dioxide-induced bronchoconstriction in asthmatic subjects. Am Rev Respir Dis 1981;123:486-91.

34 Pönkä A. Asthma and low level air pollution in Helsinki. Arch Environ Health 1991;46:262-70.

35 Bauer MA, Utell MJ, Marrow PE, Speers DM, Gibb FR. Inhalation of $0.30 \mathrm{ppm}$ nitrogen dioxide potentiates exercise-induced bronchospasm in asthmatics. Am Rev Respir Dis 1986;134:1203-8.

36 Orehek J, Massari JP, Gayrard P, Grimaud C, Charpin J. Effect of short-term, low-level nitrogen dioxide exposure on bronchial sensitivity of asthmatic patients. $\mathcal{F}$ Clin Invest 1976;57:301-7.

37 Sandström T, Andersson MC, Kolmodin-Hedman B, Stjernberg N, Angström T. Bronchoalveolar mastocytosis and lymphocytosis after nitrogen dioxide exposure in man: a time-kinetic study. Eur Respir f 1990;3:138-43. 